> Tips om medisinsk litteratur, andre bøker, filmer og elektroniske medier

som bør anmeldes, sendes tidsskriftet@legeforeningen.no

\section{Tankevekkende om sykdomsårsaker}

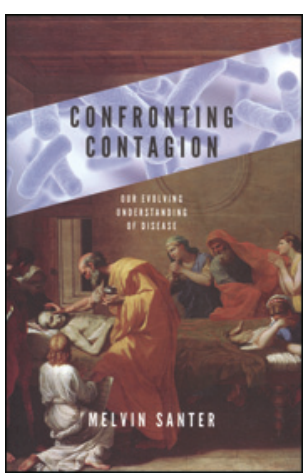

\section{Melvin Santer \\ Confronting contagion}

Our evolving understanding of disease.

353 s. Oxford: Oxford University Press, 2014.

Pris GBP 23

ISBN 978-0-19-935635-5
På omslaget omtales forfatteren som «both a lifelong biologist and an expert historian». I et personlig og derfor ganske sjarmerende forord presiserer forfatteren at hans formål er å forstå hvordan vårt syn på sykdomsårsaker har utviklet seg gjennom århundrene i lys av samtidens filosofiske og religiøse ideer. Han ønsker at leseren skal plassere seg i en tid der han, som tidens forfattere, strever med å forstå et fenomen (sykdom) som er synlig, men uforklarlig fordi dets underliggende årsaker (mikroorganismer) er usynlige og derfor umulige å ha kjennskap til.

\section{Da som nå}

Sannsynligvis for å øke leserens appetitt fremholder forfatteren innledningsvis at $\mathrm{i}$ prinsippet ble det ikke gjort noen fremskritt på 2000 år fra Hippokrates (460-370 f.Kr.) til William Harvey (1578-1657) og videre de neste 200 årene. Forfatteren fremholder at dette har sammenheng med problemet, da som nå, knyttet til det å kunne formulere fruktbare hypoteser basert på alle foreliggende data gjennom en induktiv prosess. Han benytter pesten i Athen under Peloponneskrigen (431 f.Kr.) som et eksempel, og gir nærmest en oppskrift på hvordan denne epidemien kunne vært analysert ved å innhente en rekke opplysninger. At dette ikke førte frem skyldes ifølge forfatteren at det, da som nå, nærmest er umulig å avgjøre hva som er relevant som årsaksfaktorer blant alle de opplysningene som måtte foreligge.

Selv om dette tilsynelatende kan oppfattes som et naturlig utgangspunkt, har jeg problemer med fullt ut å akseptere premisset. Her kan det være grunn til å minne om at oppskriften for analyse av pestepidemien i Athen nærmest beskriver rutinene ved utredningen av feltepidemiologiske problemstillinger i dag. Historien har også tallrike eksempler på at effektive forebyggende tiltak har vært iverksatt på grunnlag av korrekte oppfatninger av årsakssammenhenger lenge før det var mulig å påvise synlige mikroorganismer. Metoden omtales ofte i dag som «black box epidemiology» (for øvrig ikke omtalt av forfatteren), raljert over av enkelte fordi den ikke avklarer alle mellomliggende mekanismer, men som likevel har feiret store seire i forebyggende medisin. Forfatteren er naturlig nok opptatt av begrepet sykdomsårsak, men går i liten grad inn på alternative definisjoner. Han inkluderer ofte patogenetiske mekanismer blant sykdomsårsaker, noe som medfører at han stadig kommer tilbake til humoralpatologiens fire kroppsvæsker som ikke er like interessante i en etiologisk kontekst.

\section{Sykdomsårsaker}

Bortsett fra disse mer grunnleggende innvendingene gir boken en interessant oversikt over gjeldende syn på sykdomsårsaker fra tidlig hellenistisk tid frem til i dag med en rekke paradigmeskifter. Eksempelvis fant det første sted i overgangen mellom forfattere som Homer og Hesiod som mente at sykdom skyldtes guders handlinger, og de greske filosofene og Hippokrates som skyldte på naturens krefter. Aristoteles var klar over at visse sykdommer som tuberkulose og skabb kunne overføres fra person til person. Slike oppfatninger ble brakt videre i Galens (130-216) teori om årsaker til smittsomme sykdommer, riktignok sammen med faktorer som en «pestbefengt atmosfære» o.1.. Likevel introduserte Galen skillet mellom det vi i dag vil kalle nødvendige og tilstrekkelige sykdomsfremkallende faktorer. På denne måten gjennomgås hele medisinens historie frem til våre dager.

Selv om man ikke alltid vil være enig i forfatterens syn på sykdomsårsaker, gir boken et interessant grunnlag for refleksjon som kan være nyttig for kolleger som er opptatt av slike problemstillinger.

\section{Lorentz M. Irgens}

Professor emeritus, Institutt for global helse og samfunnsmedisin Universitetet i Bergen 